\title{
Optimalisasi Peran Dual Banking System Melalui Fungsi Strategis JUB Dalam Rangka Menjaga Stabilitas Sistem Keuangan di Indonesia
}

\author{
Oleh: Maulana Hamzah ${ }^{1}$
}

\begin{abstract}
We study financial system stability by concern on liquidity and effectiveness money multipler between dual banking system, both are; Sharia Banking and Conventional Banking. Research begun with historical-idealty approach and compare it to reality especially when system attacked by crisis. The Comparation Between dual banking system, show that when crisis period Sharia banking more Insusceptible than another one that because money multipler in shari'a banking is more deducated to riil sector and also he have low integrity with global economic, however the integrity has the positif side for develop economic quantity. By Monetary policy, A central bank can share this system stability adding quantity off Shari'a financial instrumen and gold in foreign exchange policy to cover system sustebcibility. Looked into inffectiveneess banking rekapitalitation, there is 2 option to protect conventional banking stability: office channeling or convertion to sharia banking. And the segmentation liquidity in money market between bank can be decreas by clearing system based on shari'a principle.
\end{abstract}

Keyword: Monetary Policy, Dual Banking system, Money Multipliers, Financial System Stability

\section{Latar Belakang Masalah}

Stabilitas keuangan adalah isu klasik yang mengiringi pertumbuhan ekonomi suatu negara, karena ia diyakini mempunyai hubungan yang positif dengan tingkat pertumbuhan ekonomi. Namun dengan banyaknya variabel makroekonomi yang mempengaruhinya ia memerlukan kebijakan moneter sebagai pioneer yang berfungsi sebagai supervisor dan regulator yang mampu mendukung dinamika pasar. Namun dengan semakin kuatnya integrasi ekonomi

${ }^{1}$ Alumni S1 Program Studi Ekonomi Islam Fakultas Ilmu Agama Islam Universitas Islam Indonesia, Yogyakarta 
antar negara, resiko moneterpun kian bertambah, seperti halnya fluktuasi ekonomi disuatu negara dapat memiliki efek domino kepada negara lainnya.

Krisis global diakhir tahun 2008 adalah contoh nyata. Kasus gagal bayar subprime mortgage pada perusahaan-perusahaan besar di Amerika memiliki dampak yang sistemik terhadap sistem perekonomian dunia. Banyaknya mata rantai krisis ini tidak lebih disebabkan oleh makin kuatnya globalisasi ekonomi terutama yang terjadi dipasar sekunder. Permainan uang menjadi uang, harus dapat dilihat secara obyektif menciptakan bubble economy yang secara logis sangat rentan untuk menciptakan krisis. Belum lagi budaya spekulasi dan short selling dalam pasar uang dan modal yang makin menciptakan ketidakpastian ekonomi. Akibatnya jumlah uang yang beredar (JUB) dimasyarakat menjadi tak menentu. Dunia perbankan dituntut memberi solusi dalam masalah ini, dengan adanya perilaku flight to quality akibat naiknya persepsi resiko investor, mayoritas bank sentral mengeluarkan kebijakan moneter yang longgar untuk meningkatkan investasi, suku bungapun cenderung turun, semua dilakukan hanya untuk meningkatkan kepercayaan pasar sehingga makin banyak uang yang beredar dan mampu memicu pertumbuhan ekonomi.

Di Indonesia dampak krisis dipasar keuangan ditandai dengan aliran modal asing yang beranjak keluar. Penurunan tingkat IHSG (Indeks Harga Saham Gabungan) dan SUN (Surat Utang Negara) memaksa pemerintah untuk mengeluarkan kebijakan strategis seperti penutupan sementara pasar saham dan pembatasan penjualan SUN. ${ }^{2}$ Secara eksplisit gejolak financial ini tidak terlalu terasa pada masyarakat karena kuantitas masyarakat Indonesia yang berkecimpung di pasar ini relatif sedikit. Namun sebenarnya dampak paling nyata yang dirasakan masyarakat adalah turunnya nilai ekspor. Dampak sistemiknya terjadi pada penurunan tingkat produksi, pengangguran dan nilai tukar rupiah yang secara teori akan menyebabkan inflasi.

Di tahun 2009 kepanikan akan imbas krisis global ternyata tidak seburuk yang ditakutkan, adanya pemilu, naiknya gaji pegawai justru membuat Jumlah Uang beredar bertambah dan perekonomian Indonesia tertolong, ${ }^{3}$ memang ada penurunan tingkat produksi namun sepertinya itu agak terbantu dengan pasar domestik yang konsumtif dan makin cinta produk dalam negeri. Namun disaat kondisi ekonomi mulai membaik nilai tukar rupiah justru mengalami depresi, bahkan lebih besar ketimbang pada saat awal krisis global diakhir tahun

${ }^{2}$ Hartadi A. Sarwono, Dampak Gejolak Eksternal pada Perekonomian Domestik serta Kebijakan yang ditempuh Pemerintah dan Bank Indonesia. Disampaikan pada Dialog Publik; "Mengkritisi Kebijakan Pemerintah dalam Penanganan Krisis Keuangan di Indonesia 2008”. diselenggarakan oleh Depkeu RI dan BEM-KM UGM Yogyakarta 23 November 2008 hal 5-6

${ }^{3}$ Direktorat Penelitian dan Pengaturan Perbankan Biro Stabilitas Sistem Keuangan, 2009, Kajian Stabilitas Keuangan No.12, Maret 2009 hal diunduh dari www.bi.go.id diakses 24 agustus 2009 
2008. Indikasi fluktuasi ekonomi ini semakin membuat sistem keuangan kian tidak stabil. Ketidak pastian ekonomi diatas setidaknya memberikan gambaran bahwa ada hubungan erat antara sistem sebagai subjek, JUB sebagai prediket dan stabilitas sebagai objek atau tujuan akhir yang ingin dicapai oleh kebijakan moneter. Maka dari itu dibutuhkanlah sebuah sistem yang lebih kebal terhadap perubahan pasar dunia yang kian terintegrasi, tanpa mengurangi akses pasar yang besar di tingkat internasional sehingga ia mampu mengendalikan JUB secara efisien dalam meningkatkan produksi dan konsumsi secara riil.

Bila melihat sistem perbankan Indonesia ditinjau dari sistem perbankan dunia pada umumnya ada perbedaan yang sangat signifikan. Sejak diberlakukannya UU no.10 tahun 1998 Di Indonesia dikenal adanya dual banking system, perbankan syariah disatu sisi dan perbankan di konvensional disisi lainnya. Walaupun terdapat 2 perbedaan sistem operasional namun secara struktural tetap dibawah naungan Bank Indonesia. Perbedaan sistem ini membuat perbedaan tingkat perkembangan juga, contoh hingga juni 2009 NPF (Non Performing Financing) bank syari'ah berada pada kisaran $7,91 \%{ }^{4}$ sedangkan bank konvensional NPL (Non-Performing Loan) nya 21\%. ${ }^{5}$ Fakta ini tentu memberi keunggulan pada perbankan syariah, terutama dalam faktor likuiditas dan daya tahannya ketika menghadapi krisis, selain faktor sistem yang lebih aman, tingkat integrasi bank syariah dengan ekonomi global dapat dibilang lebih kecil ketimbang bank konvensional.

Dengan melihat potensi dual banking system di Indonesia serta peran JUB dalam menentukan tingkat inflasi dan nilai tukar rupiah, maka dalam karya tulis ini penulis secara spesifik mengambil dua variabel tersebut sebagai variabel utama dalam mencapai tujuan stabilitas keuangan yang mendukung pertumbuhan ekonomi. Maka dari itu analisis dalam penelitian ini lebih diarahkan pada komparasi keunggulan 2 sistem perbankan dalam mengatur JUB, serta bagaimana perbedaan keunggulan dan kekurangan tersebut dapat bersinergi untuk menghadapi perubahan pasar internasional, baik pada hargaharga komoditi maupun fluktuasi nilai tukar. Dengan harapan, hasil penelitian dalam karya tulis ini dapat memberikan kontribusi akademik terhadap pengambil kebijakan moneter dan instansi berwenang lainnya khususnya Bank Indonesia dalam menjaga stabilitas keuangan yang sesuai dan mendukung pertumbuhan ekonomi untuk Indonesia yang lebih baik.

${ }^{4}$ Statistik Perbankan Syari'ah juni 2009, diunduh dari www.bi.go.id diakses 24 agustus 2009

${ }^{5}$ Statistik Perbankan Indonesia juni 2009, diunduh dari www.bi.go.id diakses 24 agustus 2009 


\section{Rumusan Masalah}

Berangkat dari latar belakang di atas, maka permasalahan yang dapat dirumuskan sebagai berikut:

a. Bagaimana potensi dual banking system dapat dioptimalkan Bank Indonesia dalam mengatur Jumlah uang beredar ideal bagi pertumbuhan ekonomi Indonesia?

b. Bagaimana keunggulan sistem ini dapat menjadi benteng ekonomi Indonesia dalam menghadapi integrasi ekonomi internasional?

\section{Tujuan Penulisan}

Berdasarkan rumusan masalah diatas, maka tujuan penulisan dalam karya tulis ini dimaksudkan untuk:

1. Mendeskripsikan dan menganalisis potensi dual banking system dapat dioptimalkan BI dalam mengtaur Jumlah uang beredar ideal bagi pertumbuhan ekonomi Indonesia

2. Mengkaji dan mendeskripsikan tata cara optimalisasi keunggulan sistem ini dapat menjadi benteng ekonomi Indonesia dalam menghadapai integrasi ekonomi internasional

\section{Landasan Teori}

\section{A. Urgensi JUB dalam Stabilitas Moneter}

Secara terminologi terdapat perbedaan Pengertian JUB (Jumlah Uang Beredar) sejak zaman ekonomi klasik hingga sekarang. Sebagian ekonom klasik mengartikan uang beredar sebagai uang kertas dan uang logam yang ada di tangan masyarakat (disebut juga uang kartal atau currency) karena hanya uang inilah yang benar-benar merupakan daya beli yang langsung bisa digunakan serta mempengaruhi harga barang. Berbeda dengan sekarang jumlah uang beredar lebih dikenal beberapa pengertian yaitu Narrow money, uang kartal dan uang giral broad money, narrow money ditambah uang quasi yang mencakup saldo deposito berjangka dan simpanan tabungan di bank. ${ }^{6}$

Dalam pembagian teori keuangan secara dikotomis, pandangan para ekonom konvensional dapat disederhanakan menjadi 2 kubu dengan 2 teori berbeda yaitu teori stock concept yang diwakili oleh kelompok Keynesian dan Marshall dan teori flow concept yang dipelopori oleh kelom monoteris, Milton Friedmen dan Irving Fisher. Perbedaan terletak pada asumsi, cara pandang dan model analisis yang diterapkan.

${ }^{6}$ Jumlah Uang Beredar. Diunduh dari www.denepraire.com di akses 26 agustus 
Misalnya dalam flow concept uang dianggap sebagai public good sedangkan dalam stock concept uang dianggap sebagai private good. Perbedaan mendasar lainnya adalah pemisahan antara uang dan modal dimana uang dianggap flow dan modal sebagai stock. Bagi kelompok kedua baik uang maupun modal semuanya dianggap sebagai stock. Kelompok flow concept juga menyatakan bahwa besarnya tingkat pendapatan masyarakat dapat diukur dan ditentukan oleh tingkat peredaran uang maka muncullah teori kuantitas uang. Ia juga menyatakan tidak ada korelasi antara kebutuhan memegang uang dengan tingkat suku bunga. Sedangkan kelompok stock concept menyatakan kebalikannya dimana kebutuhan memegang uang meruapakan indiktor bagi tingkat pendapatan masayarakat. ${ }^{7}$

Al-Maqrizi salah satu pakar ekonomi Islam yang mengambil spesialisasi masalah uang dan inflasi, berpendapat bahwa pertambahan uang harus diikuti dengan pertambahan sektor riil. Adanya uang yang berputar saja tanpa ada kaitannya dengan sektor riil itulah yang akan menyebabkan inflasi, maka dari itu ia merekomendasikan JUB dibatasi hanya pada tingkat minimal yang dibutuhkan untuk transaksi pecahan kecil. ${ }^{8}$

\section{B. Sistem Moneter di Indonesia (Tinjauan Praktis)}

Berdasarkan UU No.23 tahun 1999 Kebijakan Moneter adalah kebijakan yang ditetapkan dan dilaksanakan oleh Bank Indonesia untuk mencapai dan memelihara kestabilan nilai rupiah yang dilakukan antara lain melalui pengendalian jumlah uang beredar dan atau suku bunga. ${ }^{9}$ Secara umum kebijakan moneter merupakan kebijakan otoritas moneter atau bank sentral dalam bentuk pengendalian besaran moneter untuk mencapai perkembangan kegiatan ekonomi yang diinginkan. ${ }^{10} \mathrm{Hal}$ tersebut tercermin dari stabilitas harga yang ditandai rendahnya laju inflasi dan stabilitas nilai tukar rupiah. Maka dari itu bank sentral selaku otoritas moneter di Indonesia biasanya sudah menetapkan tingkat inflasi dan nilai tukar yang ideal bagi pertumbuhan ekonomi dengan mempertimbangkan siklus kegiatan ekonomi, sifat perekonomian suatu negara, serta faktor-faktor fundamental lainnya.

Maka dari itu disosialisasikanlah konsep ITF (Inflation Targetting Framework) yang berfungsi sebagai pedoman kebijakan moneter dalam hal. 13

7 Ahmad Dimyati, M.Ag, 2008, Teori Keuangan Islam, UII Press, Yogyakarta

${ }^{8}$ Ir. H. Adiwarman A Karim, 2001, Ekonomi Islam; Suatu Kajian Kontemporer. Gema Insani Press, Jakarta hal 68.

${ }^{9}$ Ikhtisar Undang-undang No. 23 Tahun 1999 tentang Bank Indonesia

10 Pusat Pendidikan dan Studi Kebanksentralan (PPSK), 2003, Bank Indonesia: Bank sentral republik Indonesia tinjauan kelembagaan, kebijakan dan organisasi yang diterbtkan oleh pusat pendidikan dan studi kebanksentralan bank Indonesia. Edisi pertama hal 62 
menghadapi perubahan pasar yang cepat. ${ }^{11}$ Apalagi integrasi sistem ekonomi Indonesia akibat globalisasi sudah semakin membuat inflasi dan nilai tukar dapat berubah setiap saat. Umumnya kebijakan moneter itu ada 2 yaitu easy money policy untuk memperbanyak JUB ketika terjadi kelesuan ekonomi dan tight money policy untuk memperkecil JUB ketika terjadi inflasi. ${ }^{12}$ Runtutan dampak sistemik kebijakan biasanya berawal dari BI ke perbankan baru ke masyarakat namun karena faktor integrasi ekonomi baik melalui ekspor dan kebutuhan valas peran pasar internasional menjadi variabel yang patut diperhitungkan.

Belajar dari zaman Rasulullah yang saat itu masyarakatnya juga mayoritas muslim, untuk mendorong pertumbuhan ekonomi, sekaligus stabilitas, Islam tidak melakukan ekspansi moneter melalaui pencetakan uang baru atau defisit anggaran. Yang dilakukan adalah mempercepat perputaran uang dan pembangunan infastruktur sektor riil. Faktor pendorongnya adalah kelebihan likuiditas tidak boleh ditimbun dan tidak boleh dipinjamkan dengan bunga, tapi dengan dana kebajikan baik yang berbentuk zakat produktif maupun program CSR (Corporate Social Responsbility). ${ }^{13}$ Kesuksesan ini tentu merupakan peluang bagi Indonesia yang mayoritas muslim untuk mengambil pesan positifnya, karena faktor budaya turut mempengaruhi tingkat ekonomi suatu negara.

\section{Dual Banking System Dalam Sistem Perbankan Indonesia}

Berdasarkan UU No. 23 tahun 1999 bank Indonesia adalah otoritas moneter yang memiliki tugas pokok, yaitu: (a) menetapkan dan melaksanakan kebijakan moneter; (b) mengatur dan menjaga kelancaran sistem pembayaran; dan (c) mengatur dan mengawasi bank. ${ }^{14}$ Namun Sesuai dengan UU No. 23 Tahun 1999 tentang Bank Indonesia sebagaimana telah diubah dengan UU No. 3 Tahun 2004 tujuan Bank Indonesia adalah mencapai dan memelihara kestabilan nilai rupiah (Pasal 7). Amanat ini memberikan kejelasan peran bank sentral dalam perekonomian, sehingga dalam pelaksanaan tugasnya Bank Indonesia dapat lebih fokus dalam pencapaian "single objective"-nya. ${ }^{15}$

Kestabilan nilai rupiah tercermin dari tingkat inflasi dan nilai tukar yang mendukung pertumbuhan ekonomi dan intervensi yang dilakukan dari sisi

${ }^{11}$ Materi Sosialisasi paket B Inflation Targeting Framework, 2005, Jakarta. www. bi.go.id diakses 24 agustus 2009 hal 164

${ }^{12}$ Asfia Murni, SE, M.Pd, 2006, Ekonomika Makro. PT. Reflika Aditama Bandung

${ }^{13}$ Ir. H. Adiwarman A Karim, 2001, Ekonomi Islam; Suatu Kajian Kontemporer. Gema Insani Press, Jakarta. Hal 29 2009

${ }_{14}$ Undang-Undang n0.23 tahun 1999, www.legalitas.org diakses 01 september

${ }^{15}$ Bank Indonesia dan inflasi diunduh dari www.bi.go.id diakses 24 agustus 2009 
demand yaitu melalui Kebijakan Operasi Pasar Terbuka, tingkat diskonto, GWM hingga pengaturan kredit perbankan. Namun secara syariah hal itu belum dibahas dalam UU Bank Indonesia. Padahal dalam UU No. 10 tahun 1998 dikatakan definisi bank umum adalah bank yang melaksanakan kegiatan usaha secara konvensional dan atau berdasarkan Prinsip Syariah yang dalam kegiatannya memberikan jasa dalam lalu lintas pembayaran. Payung regulasi yang ditetapkan masih sebatas regulasi adiministratif dan penetapan sistem yang dibuat sekedar memenuhi kebutuhan pasar.

Memang dengan diterbitkannya UU no.21 tahun 2008 terlihat ada respon positif bagi kesadaran akan bank dari masyakat khususnya mereka yang muslim. Namun dengan melihat perubahan pasar dan integrasi ekonomi akibat globalisasi, kiranya disinilah perlu kebijakan yang sistematik dalam memanfaatkan keunggulan dalam perbankan syariah yang diwadahi oleh dual banking system asuhan Bank Indonesia dalam menghadapi fluktuasi ekonomi global. Maka dari itu dengan adanya dual banking system, berarti telah memperkenankan dua sistem perbankan secara co-existance, meskipun masih secara implisit. Keberadaan dua sistem perbankan yang berkembang secara paralel dan yang mempunyai hubungan keuangan terbatas satu sama lain diharapkan akan dapat menciptakan diversifikasi risiko yang pada gilirannya akan mengurangi masalah systemic risk pada saat terjadi krisis keuangan.

Dengan keunggulan tersebut maka sudah selayaknyalah otoritas moneter meningkatkan signifikansi peran bank syariah dalam mendukung stabilitas sistem keuangan nasional, bersama-sama secara sinergis dengan bank konvensional dalam kerangka Dual Banking System (sistem perbankan ganda) Arsitektur Perbankan Indonesia (API). Dimana Arsitektur Perbankan Indonesia (API) merupakan suatu kerangka dasar sistem perbankan Indonesia yang bersifat menyeluruh dan memberikan arah, bentuk, dan tatanan industri perbankan untuk rentang waktu lima sampai sepuluh tahun ke depan.

\section{Tinjauan Pustaka}

Diantara penelitian terkait dengan tema ini adalah penelitian yang berjudul "Analisis Kausalitas Jumlah Uang Beredar Dengan Tingkat Inflasi Di Indonesia Tahun 1981 - 2007" yang dilakukan oleh Agus Setiawan, penelitian ini lebih banyak membahas tingkat kenaikan JUB dan perubahan harga ditinjau dari sisi historis. Hasilnya adalah hubungan yang positif anatra JUB dan inflasi, namun secara eksplisit belum secara gamblang memaparkan fungsi kebijakan moneter, terutama yang berkaitan dengan isu stabilitas keuangan. ${ }^{16}$

16 Agus Setiawan, berjudul "Analisis Kausalitas Jumlah Uang Beredar Dengan Tingkat Inflasi Di Indonesia Tahun 1981 - 2007 diunduh dari www.etd.eprint.umas. ac.id diakses 20 agustus 2009 
Dalam artikel yang ditulis oleh Zulkarnain Sitompul yang berjudul "Kemungkinan Penerapan Universal Banking System di Indonesia: Kajian dari PerspektifBank Syariah"yang lebih menganjurkan pemerintah untuk memberikan regulasi yang mendukung bank syari'ah agar dapat berkembang layaknya bank konvensional terutama dalam konteks pasar derivatif. ${ }^{17}$ Artikel ini secara eksplisit telah menawarkan konsep universal banking yang berusaha memberi keadilan bagi kedua sistem perbankan, namun konsep ini belum melihat keunggulan masingmasing pada kedua sistem, tapi lebih pada efisiensi produk dan kemudahan informasi.

Melihat fungsi JUB yang sangat central dalam mempengaruhi kebijakan moneter Sanny Naury dalam thesisnya yang berjudul "Analisis Jumlah Uang Beredar, Suku Bunga, dan Pertumbuhan Ekonomi Indonesia tahun 1997 -2002" menemukan bahwa dalam uji kausalitas granger jumlah uang beredar $(\mathrm{m} 2)$ memliki hubungan dengan tingkat bunga (i) dan pertumbuhan ekonomi (PDB) secara signifikan. Dimana peningkatan M2 akan meningkatkan nilai bunga dan peningkatan pertumbuhan ekonomi akan meningkatkan M2. Namun ia juga menemukan ternyata hasil penelitiannya bertolak belakang dengan teori Keynes yang menjadi dasar dalam analisis penelitiannya. ${ }^{18}$

Sejalan dengan hasil penelitian diatas Burhanudin Hartono seakan ikut melengkapi dengan penelitiannya yang berjudul "Analisis Simultan Jumlah Uang Beredar dan Pendapatan Nasional di Indonesia" Hasil analisis menunjukan bahwa (1) suku bunga SBI berpengaruh langsung negatif terhadap pendapatan nasional, (2) nilai tukar berpengaruh langsung dan total negatif terhadap pendapatan nasional, (3) inflasi berpengaruh langsung dan total positif terhadap pendapatan nasional, (4) kondisi perekonomian, secara statistik baik sebelum dan sesudah krisis besarnya pendapatan nasional tidak ada perbedaan, (5) suku bunga SBI berpengaruh langsung dan total positif terhadap jumlah uang beredar (6) nilai tukar tidak berpengaruh langsung dan total terhadap jumlah uang beredar, (7) uang primer berpengaruh langsung dan total positif terhadap jumlah uang beredar, dan (8) kondisi perekonomian secara statistik baik sebelum dan sesudah krisis besarnya jumlah uang beredar tidak ada perbedaan. ${ }^{19}$

Dengan demikian tulisan ini mengambil tempat sebagai penerus dan pelengkap dari tulisan-tulisan yang ada. Sebagai penjabaran lebih lanjut yang lebih lengkap dan sistematis, khususnya segala yang yang berkenaan dengan

17 Zulkarnain Sitompul "Kemungkinan Penerapan Universal Banking System di Indonesia: Kajian dari Perspektif Bank Syariah" Jurnal Hukum Bisnis, Volume 20, Agustus-September 2002

18 Sanny Naury, "Analisis Jumlah Uang Beredar, Suku Bunga, dan Pertumbuhan Ekonomi Indonesia tahun 1997 -2002" di unduh dari www.digilib.usu.ac.id diakses 20 agustus 2009

${ }^{19}$ Burhanudin Hartono, "Analisis Simultan Jumlah Uang Beredar dan Pendapatan Nasional di Indonesia" diunduh dari www.digilib.uns.ac.id diakses 20 Agustus2009 
pengeloalaan JUB dalam potensi Dual banking system. Tulisan-tulisan yang disebutkan diatas juga akan sangat membantu tulisan ini, baik sebagai bahan referensi maupun sekedar perbandingan.

\section{Metode Penulisan}

\section{A. Jenis Penelitian}

Penelititan ini merupakan penelitian deskriptif kualitatif yang bertujuan memberikan gambaran secara sistematis, faktual dan akurat mengenai fenomena yang ditulis. Penulisan dalam karya tulis ini dilakukan dengan dengan meneliti bahan pustaka dan fakta-fakta empiris dilapangan.

\section{B. Metode Pendekatan}

Metode pendekatan dalam penelitian ini menggunakan pendekatan normatif dan sosiologi pengetahuan. Penelitian normatif digunakan untuk mengkaji peluang implementasi potensi dual banking system sebagai subjek yang akan menggunakan variabel JUB (Jumlah Uang Beredar) dengan tujuan mendapat pola sistem yang tepat dalam mencapai kestabilan sistem keuangan yang mendukung pertumbuhan ekonomi. Dan sebagai salah satu syarat implementasi dilakukan pendekatan terhadap analisis ekonomi baik secara historis lalu mengkomparasikannya dengan pendekatan empiris untuk melihat pola ekonomi yang ada dan produk hukum positif yang berlaku. Sedangkan pendekatan sosiologi pengetahuan digunakan untuk mengamati dan menganalisis fakta-fakta empiris dilapangan yang didapat dari bahan pustaka yang relevan dengan pokok bahasan.

\section{Analisis Data}

Analisis data yang digunakan adalah deskriptif-kualitatif. Masalah dan fakta akan dipaparkan secara deskriptif, kemudian dianalisis guna memperoleh gambaran yang utuh tentang permasalahan-permasalahan yang diteliti, termasuk dengan melakukan analisis isi (content analysis) dan analisis SWOT. Penelitian deskriptif kualitatif yaitu sebuah penelitian yang berusaha mengungkap keadaan yang bersifat alamiah secara holistik. Penelitian kualitatif bukan hanya menggambarkan variabel-variabel tunggal melainkan dapat mengungkapkan hubungan antara satu varibel dengan variabel yang lainnya.

Dari analisis terhadap hubungan antar variabel diatas maka dapat ditarik suatu kesimpulan yang relevan untuk diterapkan tanpa harus merugikan variabel lainnya dan justru harapannya dapat memberi kontribusi yang baik untuk tiap variabel yang dianalisis. Sedangkan rekomendasi dan saran lebih difokuskan 
kepada siapa saran tersebut diajukan baru dikaitkan dengan hasil dari kesimpulan analisis data yang telah dilakukan. Sehingga akan memberikan follow-up yang tepat. Dengan harapan, hasil penelitian ini dapat berdampak langsung baik bagi pemerintah pada khususnya dan pada masyarakat pada umumnya.

\section{Pembahasan}

\section{A. Kondisi Moneter di Indonesia}

Dalam dinamika sejarah moneter Indonesia, negara ini sudah banyak mengalami pasang surut. Namun hal itulah yang seharusnya memberi gambaran praktis bagaimana mengimplementasikan suatu konsep pada kondisi. Di tahun 1960, Indonesia pernah mengalami hyperinflation hingga 600\%. Tingginya tingkat inflasi tersebut menurut banyak peneliti, terutama disebabkan terlalu banyaknya jumlah uang beredar (bahkan tidak terkendali). Baru pada tahun 1984 sampai tahun 1996 laju inflasi dapat dikendalikan pada level satu digit. ${ }^{20}$

Krisis ekonomi yang terjadi di Indonesia pada pertengahan tahun 1997 membuat laju inflasi dan JUB di Indonesia naik yaitu sebesar 11,05\% dan 78.343,- Milyar, dengan mencapai puncaknya pada tahun 1998 Inflasi sebesar 77,63 \% dengan JUB mencapai 101.197,- Milyar. Kondisi perekonomian Indonesia pasca krisis moneter mulai mengalami perbaikan. Hal ini didapat dari menurunnya laju inflasi sebesar 75,62 \% yaitu dari tahun 1998 sebesar 77,63\% menjadi 2,01\% pada tahun $1999 .{ }^{21}$

Lalu pada tahun 2001 sampai 2002 laju inflasi kembali naik pada level dua digit yaitu sebesar $12,55 \%$ dan 10,03\%. Penyebab tingginya laju inflasi tersebut selain kondisi keamanan dalam negeri yang kurang kondusif juga dipicu oleh kebijaksanaan pemerintah menaikkan harga BBM, tarif listrik dan telepon, dan tingginya JUB. Pada pertengahan tahun 2005 inflasi kembali bergejolak,yaitu sebesar 17,11 \% dan laju JUB sebesar 281.905,-Milyar. Gejolak ini dipengaruhi oleh kebijakan pemerintahan Indonesia melepas program subsidi BBM dan menaikkan harga BBM di dalam negeri. Pada tahun 2006 angka Inflasi hanya mencapai 6,6 \% dengan tingkat JUB 361.075,-Milyar. ${ }^{22} \mathrm{Hal}$ ini membawa ruang gerak yang lebih leluasa bagi Bank Indonesia untuk segera menurunkan tingkat bunga BI Rate secara bertahap. Kecenderungan ini mendapatkan respon dari kalangan usahawan dan masyarakat dengan meningkatnya tingkat kepercayaan konsumen. Perkembangan JUB di negara-negara berkembang sebenarnya tidak

${ }^{20}$ Drs. Edy suandy Hamid, M. Ec. Perekonomian Indonesia, Masalah dan Kebijakan Kontemporer. UII Press 2000 Yogyakarta hal 15.

${ }^{21}$ Agus Setiawan, berjudul "Analisis Kausalitas Jumlah Uang Beredar Dengan Tingkat Inflasi Di Indonesia Tahun 1981 - 2007 hal 2. diunduh dari www.etd.eprint. ums.ac.id diakses 20 Agustus 2009

22 Ibid hal 3 
luput dari perkembangan dan pertumbuhan lembaga-lembaga keuangan di negara tersebut khususnya Indonesia.

Berdasarkan tinjauan historis diatas terlihat Jumlah Uang Beredar (JUB) berpengaruh positif terhadap Inflasi. Peningkatan JUB yang berlebihan dapat mendorong laju Inflasi. Dan begitu juga sebaliknya jika Tingkat Inflasi tinggi, juga akan meningkatkan JUB. Pada umumnya Peningkatan jumlah uang beredar ini di Indonesia disebabkan antara lain oleh:

a) Kenaikan harga migas di luar negeri

b) Meningkatnya bantuan luar negeri

c) Masuknya modal asing, khususnya investasi portfolio di pasar uang

d) Meningkatnya anggaran Pemerintah secara mencolok

e) Depresiasi nilai Rupiah dan gejolak mata uang konvertibel ${ }^{23}$

Dampak Krisis global 2008-2009 pada negara-negara emerging market termasuk Indonesia umumnya disebabkan oleh dampak sistemik turunnya nilai ekspor namun kondisi tersebut tertolong karena cukup tingginya pertumbuhan konsumsi swasta, khususnya dari sektor-sektor non tradable seperti sektor transportasi dan komunikasi. Ditambah lagi kebijakan pemerintah berupa bantuan langsung tunai (BLT), kenaikan gaji PNS (Pegawai Negeri Sipil), dan meningkatnya intensitas kegiatan terkait dengan Pemilu cukup mampu untuk menahan laju perlambatan konsumsi. ${ }^{24}$

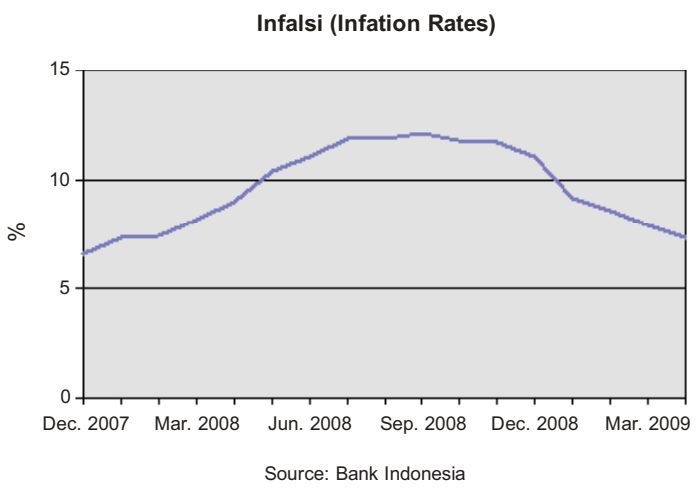

Hasilnya, Inflasi ditriwulan 1 2009 cenderung rendah karena faktor distribusi yg lancar kecuali daerah luar jawa yang masih mengalami kekurangan infrastruktur. Sampai dengan Juni 2009, kredit perbankan baru tumbuh sebesar $1,1 \%$ (ytd). Masih terbatasnya penyaluran kredit antara lain terkait dengan masih tingginya persepsi risiko di sektor riil, sementara di sisi lain, permintaan kredit juga masih rendah terkait dengan masih rendahnya kegiatan investasi. ${ }^{25}$

Konsep dual banking system sebenarnya berpotensi memberi lapisan pada sistem keuangan dimana segmentasi sistem pasar uangnya berbeda, ada PUAB di

${ }^{23}$ Ibid hal 4

${ }^{24}$ Kajian Stabilitas Keuangan No.12 Maret 2009 hal 21. www.bi.go.id diakses 24 agustus 2009

25 Tinjauan Kebijakan Moneter edisi Agustus 2009. Hal 8 www.bi.go.id diakses 24 agustus 2009 
perbankan konvensional dengan bunga sebagai daya pikatnya dan PUAS (Pasar Uang Antar Bank Syari'ah) di perbankan syariah dengan margin atau bagi hasil sebagai penariknya. PUAS disyariah cenderung lebih aman bukan hanya karena tingkat spekulasi yang rendah tapi kuantitasnya yang lebih kecil dan terkendali, sedangkan $\mathrm{PUAB}$ di konvensional cenderung spekulatif belum lagi ada segmentasi internal antara bank besar dan bank kecil, ${ }^{26}$ karena itu perlu adanya nominal anchor yang mensinergikan bank kecil dan bank besar, tanpa menjadikan fungsi the Lender of Last Resort Bank Indonesia sebagai hal yang membebani anggaran pemerintah.

\section{B. Kritik Terhadap Sistem Moneter di Indonesia}

Secara kondisional kebijakan moneter yang dilakukan pemerintah kini sudah cukup baik. Dimana ketika terjadi krisis global, dan adanya potensi efek domino akibat integrasi ekonomi. Pemerintah segera mengeluarkan beberapa kebijakan yang memproteksi kestabilan ekonomi didalam negeri diantaranya 3 perpu yang berisi masing-masing:

a. Peningkatan penjaminan oleh LPS dari semula maksimal Rp100 juta menjadi Rp2 milyar perorang pernasabah;

b. Perubahan Undang-undang tentang Bank Indonesia yang memungkinkan penggunaan kredit lancar sebagai agunan dalam mendapatkan fasilitas pendanaan jangka pendek (FPJP) dari Bank Indonesia; dan

c. Jaring Pengaman Sistem Keuangan (JPSK). ${ }^{27}$

Kebijakan ini cukup untuk menenangkan pasar, namun sebenarnya permasalahan moneter di Indonesia bukan seutuhnya berasal dari kurang lengkapnya regulasi yang mendukung atau konsep moneter yang kurang matang. Karena bila dilihat kini pemerintah sudah dapat dikatakan cepat tanggap dalam membuat regulasi yang mendukung kestabilan ekonomi. Secara sitematis masalah utama stabilitas keuangan di Indonesia terletak pada 2 hal: Law enforcement dan sistem yang rentan terhadap krisis.

Contoh nyata pada kasus BLBI (Bantuan Likuiditas Bank Indonesia) ditahun 2007 dan bank Century diawal triwulan II tahun 2009 ini. Kritik utama terhadap proses pemberian BLBI di tahun 2007 tersebut adalah kelemahan pengawasan. Seharusnya Bank Indonesia selaku pengawas bank, mengecek penggunaan pinjaman tersebut apakah benar-benar digunakan untuk membayar penarikan simpanan nasabah. ${ }^{28}$ Hal tersebut kembali terulang di tahun ini, dimana

${ }^{26}$ Kajian Stabilitas Keuangan, No.12 edisi Maret 2009. www.bi.go.id diakses 24 agustus 2009

27 Kajian Stabilitas Keuangan No,12 Maret 2009. Hal.16 www.bi.go.id. Diakses 24 agustus 2009

${ }^{28}$ S.Batunanggar Reformulasi Manajemen Krisis Indonesia: Deposit Insurance and 
reksadana "kosong" Antaboga Sekuritas tetap bebas dijual Bank Century meski sudah mendapatkan peringatan dari bank Indonesia. Akhirnya ketika terjadi gagal bayar, nasabah panik, dan kredibilitas perbankan secara sistemik terancam. Pihak pemerintahlah yang menjadi the lander of the last resort sehingga dana LPS lepas sebesar 6,77 Trilliun tanpa kepastian akan dikembalikan. Ketegasan untuk memerger, melikuidasi atau menutup suatu bank merupakan ujian nyata bagi Bank Indonesia selaku otoritas moneter.

Untuk mengatasi masalah sistem bunga ini, menilik pendapat Paul Volcker Seorang Chairman of Economic Recovery Advisory Board and former Chairman of the Federal Reserve menyarankan perlu adanya 2 lapis keuangan sistem: dengan inti pusat dari sistem tersebut, bank komersial, yang mengambil peran sebagai intitusi pelayanan yang menyediakan akses pada mekanisme kredit dan saving. Bank komersial tak perlu terkena resiko berlebihan didalam pasar dan tidak harus menjadi benteng bagi dana 2 dalam dunia usaha. ${ }^{29}$

Namun pendapat ini terkesan tidak adil karena mengorbankan pihak lain untuk kepentingan pihak lainnya. Namun yang perlu digaris bawahi disini adalah perlunya 2 lapis sistem keuangan. Di Indonesia 2 sistem itu telah ada namun tentu saja konotasinya berbeda dengan pendapat diatas, dimana keuntungan tetap dimiliki oleh kedua sistem. Yaitu konsep dual banking system dimana satu perbankan dibolehkan memiliki 2 sistem keuangan yaitu syariah dan konvensional. Baik dengan konsep office channeling maupun yang sudah dispin off, kedua sistem diatas secara nyata telah ikut mewarnai dan berkontribusi bersama dalam memajukan ekonomi bangsa.

\section{Analisis Potensi Dual Banking System dalam Kerangka Stabilitas Moneter}

\section{Analisis SWOT Sistem Perbankan Di Indonesia}

Sejak dikeluarkannya UU No. 10 tahun 1998, Indonesia memilki dua sistem dalam aktifitas perbankannya, yaitu syariah dan konvensional. Syariah dikenal dengan Bank bagi hasil yang memiliki landasan Islam dan terikat dengan lembaga independen yaitu MUI (Majelis Ulama Indonesia). Sedangkan konvensional dikenal dengan bank bunga yang sistemnya merupakan warisan ekonomi kolonial dahulu dan hampir diterapkan diseluruh dunia. Maka dari itu, Untuk mengetahui lebih lengkap dan rinci terhadap apa dan bagaimana dual banking system maka dilakukanlah analisis SWOT terhadap kualitas sistem perbankan yang ada di Indonesia dalam konteks ini adalah untuk mengetahui gambaran umum korelasi objek yang akan dianalisis dengan tujuan mencapai stabilitas moneter sebagai solusi bagi pertumbuhan ekonomi di Indonesia.

the Lender of Last Resort hal 5. diunduh dari www.bi.go.id diakses 01 september 2009

${ }^{29}$ Paul Volcker dalam http://w4.stern.nyu.edu/ di akses 24 agustus 2009 
Analisis SWOT (Strength, Weakness, Opportunities dan Threats) adalah Salah satu model perencanaan strategis. $S$ dan W mengidentifikasikan kekuatan dan kelemahan internal sistem perbankan dalam hal ini berkaitan dengan fungsi manajemen. $\mathrm{S}$ dan $\mathrm{W}$ juga mengidentifikasi kekuatan dan kelemahan pada fungsi ekonomi. Sedangkan O dan T merupakan analisis eksternal. ${ }^{30}$

\section{Analisis SWOT Perbankan Syariah.}

\section{a. Strengthness (Keunggulan)}

1) Likuiditas yang tinggi ditandai oleh FDR diatas $100 \%$. Kinerja pertumbuhan pembiayaan bank syariah tetap tinggi sampai akhir tahun 2008 dengan kinerja pembiayaan yang baik (NPF, Non Performing Financing di bawah $5 \%$ ). Penyaluran pembiayaan oleh perbankan syariah selama tahun 2008 secara konsisten terus mengalami peningkatan dengan pertumbuhan sebesar 17,6\% dari triwulan ketiga tahun 2007 atau menjadi 42,9\% pada triwulan ketiga tahun 2008. Sementara itu, nilai pembiayaan yang disalurkan oleh perbankan syariah mencapai Rp.37,7 triliun. ${ }^{31}$ Sekali lagi industri perbankan syariah menunjukkan ketangguhannya sebagai salah satu pilar penyokong stabilitas sistem keuangan nasional.

2) Tahan terhadap krisis karena minim spekulasi dan tipisnya integrasi ekonomi. Eskposure pembiayaan perbankan syariah yang masih lebih diarahkan kepada aktivitas perekonomian domestik, sehingga belum memiliki tingkat integrasi yang tinggi dengan sistem keuangan global dan belum memiliki tingkat sofistikasi transaksi yang tinggi; adalah dua faktor yang dinilai telah "menyelamatkan" bank syariah dari dampak langsung guncangan sistem keuangan global. Terbukti, selama tahun 2008 jaringan pelayanan bank syariah terus mengalami penambahan sebanyak 130 kantor cabang. Sehingga saat ini sudah ada 1.440 kantor cabang bank konvensional yang memiliki layanan syariah. ${ }^{32}$

3) Dukungan pemerintah baik melalui program akselerasi dan brand building. Dukungan positif pemerintah terlihat dari adanya ranagangan blueprint pengembangan bank syariah hingga tahun 2015, hal itu dikuti pula dengan program akselerasi dan pengenalan logo iB (Islamic Banking) sebagai brand yang mencerminkan gaya baru hidup baru dalam perbankan.

4) Pangsa Pasar yang ideal mengingat mayoritas penduduk Indonesia adalah muslim. Bank Syariah pada hakikatnya adalah bank yang dibangun dengan

${ }^{30}$ Rina Sugiarti, Ir. MM, Manajemen Strategi. Diunduh dari rinasugiarti.staff. gunadarma.ac.id/ diakses 01 september 2009

${ }^{31}$ Ramzi A. Zuhdi, Perbankan Syariah Melaju, Melintasi Guncangan, Memperkuat Stabilitas Sistem Keuangan Nasional, Diunduh dari http://ib.eramuslim.com/ diakses 01 September 2009

${ }^{32} \mathrm{Ibid}$ 
landasan nilai dan norma agama Islam. Maka mengingat Indonesia adalah negara dengan populasi terbesar didunia, hal itu tentu merupakan sebuah kekuatan tersendiri.

5) Pro terhadap sektor riil. Mendorong peran perbankan dalam menggerakkan sektor riil dan membatasi spekulasi atau tidak produktif karena pembiayaan yang dilakukan selama ini hanya ditujukan pada usaha-usaha yang berlandaskan nilai-nilai moral.

b. Weakness (Kekurangan)

1) SDI (Sumber Daya Insani), perkembangan praktek ekonomi Islam belum diimbangi dengan perkembangannya pada tataran akademik, hal ini bisa terlihat dari SDI yang sekarang berpartisipasi dalam perkembangan perbankan syariah yang masih didominasi oleh pindahan dari konvensional dan hanya sedikit yang berasal dari fresh graduate ekonomi Islam.

2) Kurang diminatinya produk bagi hasil. Hal itu salah satunya disebabkan oleh faktor resiko yang masih tinggi terkait kerugian yang dialami pihak perbankan bila berasosiasi dengan pengusaha kecil, atau pengusaha besar yang takut labanya berkurang bila berasosiasi dengan bank. ${ }^{33}$

3) Kurangnya kuantitas Bank Syariah dalam menyerap kebutuhan pasar. Dengan tingkat FDR yang diatas jumlah DPK bank syariah dapat dikatakan mempunyai likuiditas yang cukup baik, namun hal itu masih belum didukung oleh infrastruktur perbankan yang memadai hingga Juni 2009 baru ada 5 Bank Umum Syariah, 25 Unit Usaha Syariah, dan 133 Bank Pembiayaan Rakyat Syariah. ${ }^{34}$

\section{c. Opportunity (Peluang)}

1) Sebagai penopang stabilitas keuangan ketika krisis terjadi. Bank Syariah terbukti mampu mengurangi resiko yang sistemik dari kegagalan sistem keuangan di Indonesia. Hingga kini, Indonesia belum mampu untuk keluar dari kegagalan sistem keuangan yang ada selama ini. Maka dari itu, perbankan syariah merupakan alternatif untuk bisa keluar dari resiko tersebut. Sebagai bukti, bank syariah mampu survive pada saat krisis moneter tahun 1997 yang lalu. Hal ini minimal terlihat pada angka NPFs (Non Performing Financings) yang lebih rendah dibanding perbankan konvensional saat itu, disamping itu ditunjukkan dengan tidak adanya negative spread, serta konsistennya dalam menjalankan fungsi intermediasi.

2) Pembangunan ekonomi domestik. Dalam jangka pendek, perbankan syariah

${ }^{33}$ Ir. H. Adiwarman A Karim, 2001, Ekonomi Islam; Suatu Kajian Kontemporer. Gema Insani Press, Jakarta. Hal 83.

${ }_{34}$ Statistik Perbankan Syraiah di Indonesia Juni 2009, www.bi.go.id diakses 24 Agustus 2009 
nasional lebih diarahkan pada pelayanan pasar domestik yang potensinya masih sangat besar. Dengan kata lain, perbankan syariah nasional harus sanggup untuk menjadi pemain domestik akan tetapi memiliki kualitas layanan dan kinerja yang bertaraf internasional.

3) Perputaran uang yang lebih seimbang antara sektor riil dan sektor financial. Dalam konteks pengelolaan perekonomian makro, meluasnya penggunaan berbagai produk dan instrumen keuangan syariah akan dapat merekatkan hubungan antara sektor keuangan dengan sektor riil serta menciptakan harmonisasi di antara kedua sektor tersebut. Maka dari itu, disamping mendukung kegiatan keuangan dan bisnis masyarakat ia juga mengurangi transaksi spekulatif, sehingga mendukung stabilitas sistem keuangan secara keseluruhan.

\section{d. Threat (Ancaman)}

1) Pengembangan produk atau inovasi yang tidak sesuai syariah. Perkembangan suatu usaha tentu tak lepas dari kreatifitas dalam berinovasi dan menciptakan produk baru, hal itu semata didorong oleh tuntutan persaingan pasar yang sangat ketat. Namun dalam konteks perbankan syariah yang operasionalnya memang harus mengedepankan nilai agama dulu baru aspek bisnis, hendaknyalah inovasi berawal dari pengembangan wacana dalam fiqh mu'amalah baru disesuaikan dengan kebutuhan pasar dan bukan sebaliknya.

2) Ancaman negative spread, dimana tingkat FDR yang diatas DPK. ${ }^{35}$ Hingga Juni 2009, total pembiayaan bank syariah senantiasa berada diatas total DPK, hal ini tentu akan beresiko bila terjadi gagal bayar, sedangkan bank tidak memiliki cadangan dana yang cukup, bila terjadi penarikan.

\section{Analisis SWOT Perbankan Konvensional}

\section{a. Strengthness (Keunggulan)}

1) Pangsa pasar yang besar dan mayoritas. Sebagaimana diketahui secara umum bank konvensional memiliki lebih dari $95 \%$ pangsa pasar perbankan nasional. ${ }^{36} \mathrm{Hal}$ ini tentu memberikan kekuatan jaringan yang sangat besar. Baik dari sisi funding, lending maupun service. Hingga kini dapat diketahui peran perbankan konvensional yang sudah ada dalam memberikan kemudahan transaksi.

2) Sistem manajemen yang sudah kuat dan teruji secara struktural. Pelajaran krisis diakhir masa orde baru telah memberi inspirasi baru bagi Bank Indonesia untuk memberikan pelatihan manajemen sumber daya manusia

${ }^{35}$ Ibid

${ }^{36}$ Statistik Perbankan Indonesia juni 2009, di unduh dari www.bi.go.id diakses 24 agustus 2009 
secara berkesinambungan. Selain itu infrastruktur perbankan kini sudah lebih baik, seperti adanya LPS (Lembaga Penjamin Simpanan), ITF (Inflation Targetting Framework), dan KSSK (Komite Stabilitas Sistem Keuangan).

3) Akses Modal yang besar. Ada 2 faktor yang mempengaruhi yaitu mayoritas penduduk di Indonesia dan didunia masih menggunakan jasa perbankan konvensional untuk menyimpan atau meminjam uangnya. Selain itu faktor integrasi ekonomi telah membuat akses pendanaan bank semakin mudah dan beragam.

b. Weakness (Kekurangan)

1) Pergerakan nilai tukar yang fluktuatif, hal itu dibarengi pula dengan tanggapan yang minim dari pihak perbankan terhadap penentuan BI rate. Dalam sistem moneter internasional, dollar adalah acuan utama dalam menentukan nilai tukar, ia juga menjadi alat pembayaran yang umum digunakan dalam praktek ekspor dan impor.

2) Integrasi yang kuat dengan sistem moneter global. Dengan pola floating money yang sudah terintegrasi tentu akan memberi dampak "ketidakpastian ekonomi”. Belum lagi budaya spekulasi dan short selling yang membuat pasar uang dalam perbankan makin tak menentu.

3 Rentan terhadap krisis. Dengan adanya fluktasi moneter dan globalisasi ekonomi tentu akan membuat anacaman krisis semakin nyata. Itulah yang dianggap konskuensi dari integrasi ekonomi, karena krisis disuatu negara dapat berdampak pada negara lainnya.

c. Opportunity (Peluang)

1) Punya akses modal yang besar pada pembiayaan pembangunan ekonomi. Dalam konteks pembangunan ekonomi terutama infrastruktur yang mendukung aspek distribusi, peran perbankan tentu tak dapat disangsikan, karena itu bila penggunaan dana dalam perbankan lebih tepat guna dan berbasis sektor riil tentu akan semakin mempercepat pertumbuhan ekonomi di Indonesia.

2) Mampu bersinergi dengan bank-bank besar di tingkat internasional. Harus diakui bank konvensional memang meiliki akses yang kuat pada institusi moneter internasional, selain karena bank pusatnya ada di luar negeri, kesamaan sistem telah memudahkan prosedur kerjasamanya. Maka dari itu peluang pendanaan modal untuk pengembangan dan wacana strategi kebijakan yang luas sangat mudah didapatkan.

\section{d. Threat (Ancaman)}

1) Kredibilitas yang kian menurun karena faktor integrasi global yang tidak menentu. Dengan banyaknya kasus bank gagal di Indonesia (misalnya Century) telah membuat kredibilitas bank secara umum di Indonesia 
mengalami distorsi. Kebijakan merger, akuisisi, hingga rekapitalisasi kedepannya di nilai tidak lagi efektif karena masyarakat Indonesia sudah kian cerdas dalam memilih perbankan yang kredibel untuk menyimpan uangnya. Hal ini tentu sangat ironis mengingat perbankan merupakan lembaga yang di tuntut untuk menjaga kredibilitas.

2) Sistem moneter yang rentan terkena krisis. Selama Indonesia masih menggunakan sistem moneter yang mengambang, krisis adalah sesuatu yang tidak bisa di hindari, karena resiko yang ada akan selalu muncul walaupun terus diminimalisir, namun dalam konteks global hal itu memang hal yang tidak bisa di hindari, maka dari itu disinilah pentingnya ada sistem lain yang mampu menopang kekurangan ini.

3) Adanya aliran kredit keluar negeri. Rata-rata hampir semua bank swasta di Indonesia dimiliki oleh pihak asing. Hal ini tentu memiliki resiko pengumpulan dana yang terjadi didalam negeri, dialihkan untuk membiayai kredit diluar negeri. Sedangkan modal CAR (Capital Adequati Ratio) selalu mendapat suntikan dari bank pusatnya diluar negeri.

Dengan terciptanya dual banking system yang utuh, sistem ini dapat mengakomodir perbankan konvensional maupun perbankan dengan prinsip syariah. Artinya, dengan adanya mekanisme yang tepat dalam pengelolaan dual banking system maka penggunaan perbankan konvensional dan syariah yang berjalan secara paralel akan lebih kuat. Adanya dua sistem perbankan yang berkembang dalam satu undang-undang sesungguhnya mempunyai hubungan kuangan yang terbatas satu sama lain akan menciptakan diversifikasi risiko keuangan secara beragam. Untuk itulah, keduanya harus dipisahkan, sehingga bank syariah dapat berkonstribusi secara signifikan dalam meningkatkan ketahanan sistem perbankan nasional. ${ }^{37}$

\section{Efektifitas JUB dalam Sistem Perbankan Di Indonesia}

Pertumbuhan ekonomi di Indonesia tidak lepas dari keterlibatan sektor moneter dan perbankan. Ia dianggap mempunyai fungsi yang mampu memberikan pelayanan bagi berlangsungnya sektor riil, baik kegiatan investasi, produksi, distribusi, maupun konsumsi. Harapannya dengan meningkatnya pertumbuhan sektor riil akan memacu peningkatan jumlah uang yang beredar secara efektif yang pada akhirnya dapat meningkatkan kegiatan ekonomi dan belanja negara.

Di Indonesia kebijakan JUB memang berada pada satu payung otoritas moneter yaitu Bank Indonesia. Namun dalam pengelolaannya Indonesia memiliki 2 sistem perbankan yaitu bank syariah dan bank konvensional. Dengan 2 sistem

${ }^{37}$ Mustafa Kamal Rokan. Urgensi Perbankan Syariah diunduh dari www.waspada. co.id di akses 01 September 2009 
yang berbeda dimana satu sistem menganut bunga dan lainnya bagi hasil terutama akan menghasilkan 2 pengeloaan dan 2 jenis efektifitas yang berbeda. Secara mendasar Perbedaan kedua sistem itu dalam fungsinya mengatur JUB dapat terlihat pada:

\begin{tabular}{|l|l|l|}
\hline & \multicolumn{1}{|c|}{ Bank Syariah } & \multicolumn{1}{c|}{ Bank Konvensional } \\
\hline Konsep & Bagi Hasil & Bunga \\
\hline Standar nilai uang & Emas & Floating Money (dollar) \\
\hline Tingkat Integrasi & Lemah & Kuat \\
\hline
\end{tabular}

Dengan perbedaan konsep pada sistem intermediasi diantara kedua sistem tersebut maka kebijakan menaik-turunkan bunga tidak berlaku dalam perbankan syariah. Karena itu ketika krisis atau inflasi terjadi bank syariah hampir tidak tersentuh kebijakan moneter. Selain itu melihat tingkat likuiditas yang tinggi dari bank syariah dimana rata-rata FDR nya diatas DPK, hendaknya kebijakan moneter diarahkan pada bagaimana memberi pinjaman pada perbankan syariah baik melalui operasi pasar terbuka dengan meningkatkan Jumlah SBSN (Surat Berharga Syari'ah Negara) agar bank syariah dapat menambah kuantitas modal untuk memenuhi likuiditas mereka tanpa menggangu tingkat CAR yang telah dicanangkan oleh Bank indonesia.

Hal ini selain dapat mengurangi dampak spekulasi bunga, juga setidaknya dapat membuat aliran uang yang beredar menyentuh sektor riil. Dan tidak hanya berhenti pada pengembalian kepercayaan pasar secara jangka pendek, karena kalkulasi iklim ekonomi seperti itu hanya akan menjadi makanan empuk bagi para spekulan untuk mengeruk keuntungan. Sedangkan masyarakat yang menjadi objek kesejahteraan ekonomi, hanya sedikit yang merasakan efek positif dari kebijakan moneter.

Yang kedua kita melihat standar nilai mata uang bank syariah idealnya adalah emas. Namun harus diakui memang belum terealisasi. Dalam berbagai penelitian sudah banyak dikatakan emas lebih stabil dalam menghadapi perubahan pasar. Maka dari itu efek positif konsep emas ini sebenarnya dapat dimulai dari meningkatkan cadangan devisa emas dan transaksi dengan standar emas pada pasar Timur Tengah. Selain penggunaan dollar masih tetap dijalankan sebagai alat pembayaran internasional, namun setidaknya Indonesia juga memiliki back-up pasar yang cukup produktif manakala pasar global mengalami collapse.

Sedangkan yang ketiga dengan kuatnya integrasi ekonomi, seharusnya dapat meningkatkan jejaring konsep bagi hasil yang stabil dalam perbankan konvensional terutama melalui peran office channeling. Selain dapat menigkatkan efektifitas JUB ia juga kan memberikan back-up yang kuat dalam operasional bank konvensional. Bila diruntut secara sistematis ketika terjadi krisis ada perbedaan yang cukup signifikan antar Bank Syariah dan Bank Konvensional yaitu:

- Integrasi ekonomi-krisis global-flight to quality-easy money policy-JUB stabil untuk jangka pendek-punya resiko jangka panjang (dalam Sistem Perbankan Konvensional) 
- Integrasi ekonomi-krisis global-instrumen modal syariah stabil-likuiditas stabil-JUB alam konteks stabil-resiko eksternal. (dalam Sistem Perbankan Syariah)

Dengan adanya dual banking system perekomian indnesia selalu punya akses modal yang seimbang walaupun terjadi krisis. Sekaligus dapat mengurangi aspek spekulasi dan derivasi dipasar uang. Artinya JUB akan selalu seimbang dengan kebutuhan ekonomi.

\section{E. Stabilisasi Sistem Keuangan Melalui Fungsi Strategis JUB Dalam Dual Banking System}

Pengembangan dual banking system di Indonesia dilakukan dalam kerangka Arsitektur Perbankan Indonesia (API). Secara bersama-sama, sistem perbankan syariah dan perbankan konvensional secara sinergis mendukung mobilisasi dana masyarakat secara lebih luas untuk meningkatkan kemampuan pembiayaan bagi sektor-sektor perekonomian nasional. ${ }^{38}$ Maka secara garis besar alur stabilasi keuangan melalui fungsi dual banking system dapat digambarkan sebagai berikut:

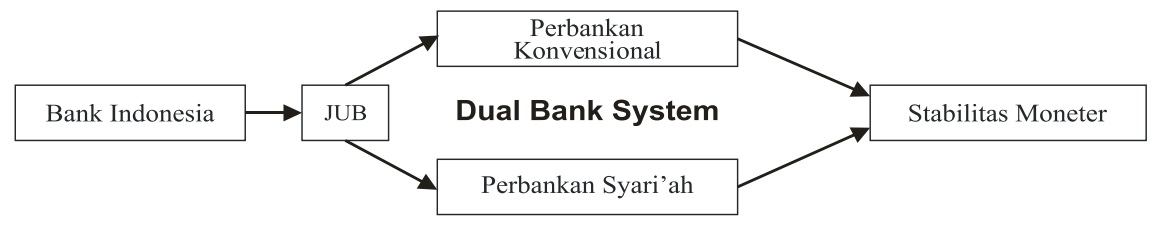

Dalam kerangka kebijakan moneter yang sudah ada, biasanya Bank Indonesia selalu memiliki target inflasi dan target ekonomi yang akan diraih dimasa depan berdasarkan pertimbangan kekuatan ekonomi kini dan tantangan dimasa depan. Hal itu biasanya dilakukan dengan kebijakan penentuan tingkat suku bunga atau yang dikenal dengan $B I$ rate, namun fakta dilapangan terlihat bahwa tingkat suku bunga perbankan jauh dari tingkat $B I$ rate. Sehingga penentuan tingkat suku bunga oleh otoritas moneter ibarat obat untuk menyenangkan pasar dan hanya memiliki implikasi ekonomi yang minim secara praktis. Karena itu diperlukanlah kiranya ketegasan moneter dalam untuk menangani hal tersebut, kalau perlu Bank Indonesia dapat membentuk DPP (Dewan Pengawas Perbankan) seperti halnya DPS dalam perbankan Syariah yang menilai tingkat kepatuhan perbankan pada regulasi yang dibuat otoritas moneter. Berdasarkan pengalaman kasus negative spread di Indonesia, kebanyakan berasal dari lemahnya pengawasan dan bukan karena minimnya regulasi.

Salah satu permasalahan yang belum selesai adalah masalah pasar uang

${ }^{38}$ Muhammad Iqbal Gifari, Sekilas Perbankan Syariah Di Indonesia. Di unduh dari www.islamiccenter.net diakses 01 september 2009 
antar bank, yang dipicu aksi segmentasi perbankan besar dan bank-bank kecil. Belajar dari Malaysia, otoritas moneternya membuat sistem kliring antar bank yang harus diikuti oleh bank syariah dan konvensional yang menjalankan SPTF (Skim Perbankan Tanpa Faedah) semacam simpanan bank tanpa bunga. Bankbank ini harus menyimpan GWM di bank sentral dengan skim wadiah, kemudian kliring otomatis dilakukan. Jadi bank-bank yang mempunyai kelebihan likuiditas secara otomatis akan menempatkan dananya di bank-bank yang kekurangan dengan skim mudharabah. ${ }^{39}$ Selain lebih aman karena faktor spekulasi yang tidak sebesar bunga, konsep ini dapat diterima oleh kedua sistem perbankan.

Dengan adanya pola kliring seperti penjelasan diatas diharapkan dampak sistemik yang mungkin suatu saat dialami suatu bank, tidak terlalu besar. Sehingga tidak membebani negara untuk merekapitalisasi bank yang pailit tersebut. Selain dana yang tidak sedikit, rekapitalisasi perbankan juga cenderung membuat jumlah uang beredar hanya berputar pada tataran spekulasi yang cukup besar. Karena tingkat kepercayaan nasabah terhadap kredibilitas perbankan yang pailit sudah terlanjur menurun, maka dari itu sejak krisis 1997 kebijakan moneter ada yang diarahkan pada kegiatan merger, akuisisi, hingga likuidasi terbilang lebih efektif. Namun dengan perkembangan bank syariah kini, dan adanya potensi dual banking system, ada baiknya kebijakan terhadap bank bermasalah melirik ke arah konversi, yaitu konversi bank konvensional menjadi bank syariah yang lebih stabil dalam alur keuangannya. Hal itu dapat dilakukan dengan dua pendekatan yaitu membuka Unit Usaha Syariah dengan prinsip office channeling atau langsung di spin-off.

Kebijakan konversi diatas juga cenderung akan meningkatkan kuantitas bank syariah sehingga pangsa pasar bank yang tahan krisis ini makin luas. Ketahanan krisis perbankan syariah ini ternyata tak hanya diakui di Indonesia bahkan negara-negara post kapitalispun banyak yang tertarik dengan sistem ini seperti Jepang dan Inggris. Bahkan Singapura pun telah mencanangkan akan menjadi pusat bank syariah Asia Tenggara. Maka dari itu untuk mendukung program akselerasi perbankan syariah perlulah dikaji kembali tentang menjadikan salah satu bank syari'ah sebagai BUMN (Badan Usaha Milik Negara),${ }^{40}$ dengan harapan mampu menopang pembiayaan BUMN sekaligus sumber pendapatan yang produktif bagi APBN (Anggaran Pendapatan dan Belanja Negara).

Dengan keunggulan sistem Syariah terhadap sistem konvensional dalam hal stabilitas, dan keunggulan bank konvensional terhadap bank syariah dalam hal akses pasar dan modal hendaknyalah menjadi sebuah sinergi kekuatan yang saling melengkapi dalam menciptakan stabilitas keuangan yang mendukung pertumbuhan ekonomi di negeri Indonesia tercinta ini.

${ }^{39}$ Adiwarman A Karim, 2001, Ekonomi Islam; Suatu Kajian Kontemporer. Gema Insani Press, Jakarta. Hal 127

${ }^{40}$ Rohaya, Hairiennisa, S.Ei, 2008, Perkembangan Skala Usaha Perbankan Syariah di Indonesia Pra dan Pasca Kebijakan Office Channeling. Penelitian ini merupakan skripsi di Program Studi Ekonomi Islam, UII. Yogyakarta. Hal 81 


\section{Penutup}

Berdasarkan analisis permasalahan diatas dihasilkanlah hasil penelitian yang dapat disimpulkan sebagai berikut:

a. Potensi dual banking system di Indonesia dapat dioptimalkan melalui strengtness share dan weakness cover, dimana bank syariah secara umum mempunyai keunggulan dalam hal sistem yang lebih stabil dalam menghadapi perubahan pasar namun memiliki kekurangan dalam hal infrastruktur, sedangkan bank konvensional mempunyai akses pasar dan modal yang besar dan infrastruktur yang lebih lengkap, namun sangat rentan terhadap krisis karena faktor negatif integrasi ekonomi yang sudah sangat kuat.

b. Untuk mencapai efektifitas JUB terhadap pertumbuhan sektor riil dan lebih stabil terhadap perubahan pasar, dapat dilakukan dengan 2 cara yaitu penerbitan instrumen moneter syariah yang lebih lengkap seperti SBSN (Surat Berharga Syari'ah Negara), ORI (Obligasi Ritel Indonesia) berbasis syariah dan bank konvensional juga dapat berperan disini melalui pengurangan penggunaan instrumen derivatif. Yang kedua adalah menambah kuantitas emas dalam cadangan devisa. Hal ini dengan melihat semakin prospektifnya dana Timur Tengah, terutama disaat krisis sebagai sumber investasi baru.

c. Keunggulan konsep dual banking system ini terlihat pada 2 sistem yang terpisah yang secara operasional tidak mempengaruhi satu sama lain, namun memiliki satu tujuan yang sama yaitu stabilitas keuangan yang mendukung pertumbuhan ekonomi. Maka untuk mencapai tujuan tersebut kedua sistem dapat bersinergi dalam faktor-faktor yang bersifat eksternal seperti akses modal, infrstruktur, pengawasan atau sistem kliring yang mampu membantu likuiditas antar bank.

d. Sistem kliring berbasis syari'ah. Dengan sistem kliring yang lebih condong kearah syariah, dimana instrumen wadiah dan mudharabah diterapkan. Tentu mampu mempertemukan bank syariah yang terikat nilai dan bank konvensional yang bebas nilai. Karena secara ekonomipun sistem ini akan membantu memenuhi kebutuhan modal dan kelancaran likuiditas. Selain itu kebijakan konversi bank konvensional ke bank syariah juga dapat menjadi alternatif solusi dalam menyelamatkan suatu bank ketimbang rekapitalisasi yang cenderung mengundang kontroversi.

\section{DAFTAR PUSTAKA}

\section{Buku, Jurnal dan Makalah.}

A Karim, Ir. H. Adiwarman, 2001, Ekonomi Islam; Suatu Kajian Kontemporer. Penerbit Gema Insani Press, Jakarta.

A Karim, Ir. H. Adiwarman, 2007, Ekonomi Makro Islami, PT Raja Grafindo Perkasa, Jakarta. 
Achmad Tohirin, 2003, Implementasi Perbankan Islam: Pengaruh Sosio-Ekonomis dan Peranannya dalam Pembangunan, dalam Jurnal Ekonomi Pembangunan Kajian Ekonomi Negara Berkembang Vol. 8 No. 1, Hal: 73 - 88

Booklet Perbankan Indonesia 2009, diterbitkan oleh Direktorat Perizinan dan Informasi Perbankan, Bank Indonesia Jakarta

Christine E. Blair and Rose M. Kushmeider, 2006, Challenges to the Dual Banking System: The Funding of Bank Supervisio. FDIC Banking Review, volume 18 no.1. diunduh dari www.fdic.gov.

Dr. HRA Rivai Wirasasmita, SE. M.Si, Dr. H. Maman Kasiman Sulaiman, SE MBA, Ronald Sitorus, Brenggar Manarung, 2002, Kamus Lengkap Ekonomi, Penerbit Pioneer Jaya, Bandung.

Drs. Edy suandy Hamid, M. Ec. 2000. Perekonomian Indonesia, Masalah dan Kebijakan Kontemporer. UII Press Yogyakarta

Dimyati, Ahmad, M.Ag, 2008, Teori Keuangan Islam, UII Press, Yogyakarta Rohaya, Hairiennisa, S.Ei, 2008, Perkembangan Skala Usaha Perbankan Syariah di Indonesia Pra dan Pasca Kebijakan Office Channeling. Penelitian ini merupakan skripsi di Prodi Ekonomi Islam, Universitas Islam Indonesia. Yogyakarta.

Sarwono, Hartadi A, 2008, Dampak Gejolak Eksternal pada Perekonomian Domestik serta Kebijakan yang ditempuh Pemerintah dan Bank Indonesia. Disampaikan pada Dialog Publik; "Mengkritisi Kebijakan Pemerintah dalam Penanganan Krisis Keuangan di Indonesia 2008”. Yang diselenggarakan oleh Depkeu RI dan BEM-KM UGM Yogyakarta 23 November 2008.

Idrus, Muhammad, 2007, Metode Penelitian Ilmu-Ilmu Sosial (Pendekatan Kualitataif dan Kuantitatif), UII Press Yogyakarta.

Kodifikasi Produk Perbankan Syari'ah, diterbitkan oleh Direktorat perbankan Syariah 2008 Jakarta

L. Brue, Stanley, 2000, The Evolution of Economic Thought, Sixth edition. The Dryden Press, Orlando.

Assidique, Muhammad dan Nomura, Nauto, 2008, Penjelasan Terhadap Krisis Financial Global, disampaikan dalam International Conference of Islamic Economic System di Jogja Expo Center 27 Desember 2008.

Murni, SE, M.Pd, Asfia, 2006, Ekonomika Makro. PT. Reflika Aditama Bandung.

Ndikumana, Leonce, 2001, 'Financial Development, Financial Structure, and Domestic Investment: International Evidence," Working Paper Series \# 16, Policy Economic Research Institute, University of Massachusetts, Amherst.

Samuelson, Paul A. Dan D Nordhaus, William. 1992, Makroekonomi edisi keempat belas. Penerbit Erlangga, Jakarta.

Prof. Dr. M. Umer Chapra, 1997, Al-Qur'an, Menuju Sistem Moneter Yang Adil. 
Penerbit Dana Bhakti Prima Yasa Yogyakarta.

Pusat Pendidikan dan Studi Kebanksentralan (PPSK), 2003, Bank Indonesia: Bank Sentral Republik Indonesia Tinjauan Kelembagaan, Kebijakan, dan

Organisasi. Diterbitkan oleh PPSK - Bank Indonesia, Jakarta.

Djojohadikusumo, Sumitro, 1991, Perkembangan Pemikiran Ekonomi, Yayasan Obor Indonesia Jakarta.

Winarno Surakhmat, 1994, Pengantar Penelitian Ilmiah: Dasar Metode Teknik. Bandung.

Zulkarnain Sitompul "Kemungkinan Penerapan Universal Banking System di Indonesia: Kajian dari Perspektif Bank Syariah" Jurnal Hukum Bisnis, Volume 20, Agustus-September 2002

\section{Surat Kabar, Majalah dan Internet}

http://www.etd.eprint.umas.ac.id diakses 20 agustus 2009 http://www.digilib.uns.ac.id diakses 20 agustus 2009 http://www.occ.treas.gov diakses 24 agustus 2009

http://www.denepraire.com di akses 26 agustus 2009 http://www.myunanto.staffgunadarma.ac.id diakses 01 september 2009 http://www.islamiccenter.net diakses 01 september 2009 http://www.waspada.co.id di akses 01 september 2009 http://www.digilib.ui.ac.id/ dikases 30 agustus 2009 http://w4.stern.nyu.edu/news/news.cfm?doc_id=101000 diakses 24 agustus 2009

http://ib.eramuslim.com/ diakses 01 september 2009

http://www.rinasugiarti.staff.gunadarma.ac.id/ diakses 01 september 2009 http://www.digilib.usu.ac.id diakses 20 agustus 2009 http://www.legalitas.org diakses 01 september 2009 http://www.aeaweb.org/journal/jel_class_system.html diakses 24 agustus 2009 http://www.bi.go.id/web/id/Publikasi/ diakses 20, 24, agustus 2009 dan 01 september 2009

http://www.cepr.org/pubs/new-dps/dplist.asp?dpno=6984.asp http://www.re-searchengines.com/dwi1008.html. diakses 20 agustus 2009 Majalah Sharing Edisi 32 Thn III Agustus 2009 hal 14 -15.

Peraturan Perundang-Undangan

Ikhtisar Undang-undang No. 23 Tahun 1999 tentang Bank Indonesia

Peraturan Pemerintah Pengganti Undang-Undang Republik Indonesia No 2 Tahun 2008 Tentang Perubahan Kedua Atas Undang-Undang Nomor 23 Tahun 1999 Tentang Bank Indonesia 
Undang-Undang Republik Indonesia Nomor 10 Tahun 1998 Tentang Perubahan Atas Undang-Undang Nomor 7 Tahun 1992 Tentang Perbankan.

Undang-Undang Republik Indonesia Nomor 7 Tahun 199 Tentang Perbankan Sebagaimana Telah Diubah Dengan Undang-Undang Nomor 10 Tahun 1998

Undang-Undang Republik Indonesia Nomor 21 Tahun 2008 Tentang Perbankan Syariah 